\title{
A giant lymphangioma circumscriptum on the anterior axilla: A case report
}

\author{
Ibrahim Askar MD ${ }^{1}$, Nihal Kilinc $M D^{2}$, Sema Aytekin MD $^{3}$
}

I Askar, N Kilinc, S Aytekin. A giant lymphangioma circumscriptum on the anterior axilla: A case report. Can J Plast Surg 2003;11(3):157-159.

Lymphangioma is a rare benign proliferative lymphatic lesion that appears in chronic lymphedematous states in a variety of settings. Lymphangioma circumscriptum consists of clinically thin-walled, translucent vesicles appearing in groups most commonly located on the axilla, chest, mouth, and tongue. A 12-year-old male patient had been suffering from itching, pink-red colored, translucent vesicular lesions overlying the anterior axilla since birth. The lesions had slowly grown in size and number over the years. The patient had no history of trauma, or cellulites. The physical examination revealed clusters of pink-red colored vesicles, which released a clear exudate when punctured. The lesion was $50 \times 120 \mathrm{~mm}$ in size. The lesion was totally excised and repaired with Z-plasty. Histopathological examination revealed slight epidermal acanthosis and enlarged lymph in the upper dermis, impinging directly onto the epidermis. These lymphatics were lined only by endothelium. The lower dermis and subcutis contained abnormally large muscle-coated vessels containing a proteinaceous fluid. Six months later, there was no recurrence and a cosmetically and functionally acceptable postoperative result was obtained.

Key Words: Axilla; Lymphangioma circumscriptum; Z-plasty

\section{Rapport de cas d'un lymphangiome géant délimité dans le creux axillaire antérieur}

Le lymphangiome est une lésion proliférative bénigne et rare qui fait son apparition dans des états lymphœdémateux chroniques à divers foyers. Le lymphangiome délimité se compose cliniquement de vésicules translucides aux parois minces qui apparaissent en groupes et qui s'observent surtout dans le creux axillaire, sur la poitrine, dans la bouche et sur la langue. Depuis la naissance, un garçon de 12 ans présentait des lésions vésiculaires démangeantes, rôsatres et translucides sur le creux axillaire antérieur. Les lésions s'étaient lentement élargies et avaient augmenté en nombre au fil des ans. Le patient n'avait aucun antécédent de traumatisme ou de cellulite. L'examen physique a révélé des grappes de vésicules rosâtres qui libéraient un exsudat clair lorsqu'elles étaient percées. La lésion était de $50 \mathrm{~mm} \times 120 \mathrm{~mm}$. Elle a été entièrement excisée et réparée par plastie en Z. L'examen histopathologique a révélé une légère hyperacanthose et une hypertrophie lymphatique dans le derme supérieur, empiétant directement sur l'épiderme. Ces vaisseaux lymphatiques n'étaient tapissés que par l'endothélium. Le derme inférieur et l'hypoderme contenaient des vaisseaux recouverts de muscles anormalement larges, contenant un liquide protéique. Six mois plus tard, on ne remarquait aucune récurrence, et le résultat postopératoire était esthétique et accep-table d'un point de vue fonctionnel.
$\mathrm{L}_{\mathrm{p}}^{\mathrm{p}}$ ymphangioma is a rare benign proliferative disorder of lym-

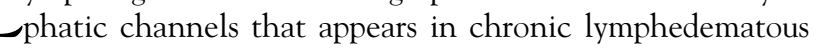
states in a variety of settings (1). Lymphangioma circumscriptum consists of clinically thin-walled, translucent vesicles appearing in groups most commonly located on the axilla, chest, mouth, and tongue $(2,3)$. These persistent vesicles contains colorless fluid and sometimes blood (4). We present a case of giant lymphangioma circumscriptum on the anterior axilla.

\section{CASE PRESENTATION}

A 12-year-old male patient had been suffering from itching, pink-red colored, translucent vesicular lesions overlying the anterior axilla since birth. The lesions had slowly grown in size and number over the years. The patient had no history of trauma, or cellulites. The physical examination revealed clusters of pink-red colored vesicles, which released a clear exudate when punctured (Figure 1). The lesion was $50 \times 120 \mathrm{~mm}$ in size. The rest of the physical examination was normal. The lesion was totally excised and repaired with Z-plasty. The sample was sent to pathology. Histopathological examination revealed slight epidermal acanthosis and enlarged lymph in the upper dermis, impinging directly onto the epidermis (Figure 2). These lymphatics were lined only by endothelium. The lower dermis and subcutis contained abnormally large muscle-coated vessels containing a proteinaceous fluid. Six months later, there was no recurrence and a cosmetically and functionally acceptable postoperative result was obtained (Figure 3).

\section{DISCUSSION}

Lymphangioma circumscriptum was first described as "lymphangiectodes" by Tidbury Fox and Colcott Fox in 1878. Malcolm Morris first used the term "lymphangioma circumscriptum" in 1889 (3). Lymphangioma circumscriptum is thought to represent a developmental abnormality. The subepidermal lymphatic vesicles are defined as endotheliumlined spaces which are completely separate from the normal lymphatic system (5). Peachey et al (6) described three groups of lymphangioma circumscriptum. The first group included classical lesions involving larger skin areas, which are pro-

${ }^{1}$ Plastic and Reconstructive Surgery; ${ }^{2}$ Pathology; ${ }^{3}$ Dermatology, Dicle University, Medical School, Diyarbakir, Turkey

Correspondence: Dr Ibrahim Askar, Dicle University, Medical School, Department of Plastic and Reconstructive Surgery, Diyarbakir Turkey.

Telephone +90-412-248-80-01/40-39, fax+90-412-224-79-45, e-mail iaskar@superonline.com 


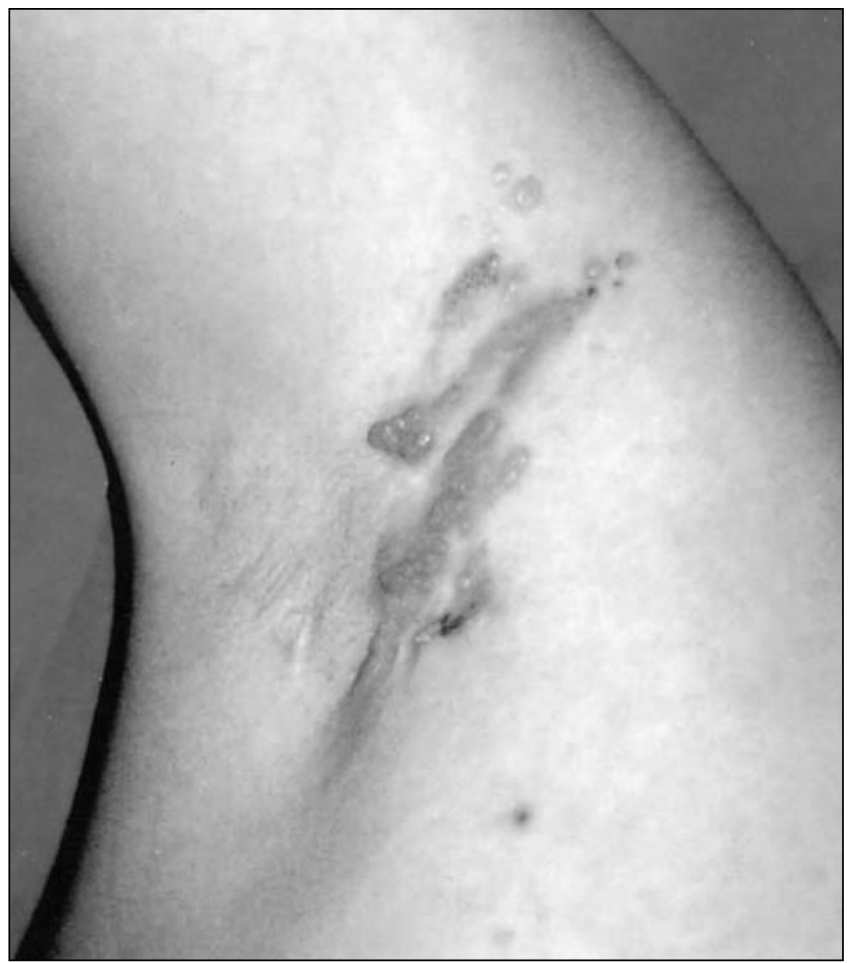

Figure 1) A 12-year-old male patient had been suffering from itching, pink-red colored, translucent vesicular lesions overlying anterior axilla

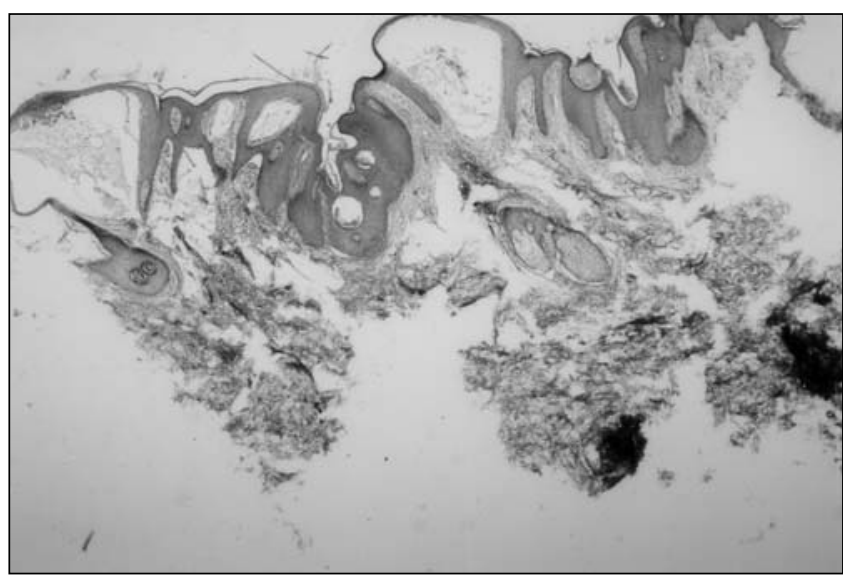

Figure 2) Histopathological examination revealed enlarged lymphatic vessels in the upper dermis, impinging directly onto the epidermis (Hematoxylin and eosin stain, original magnification $\times 100$ )

duced by rhythmically contracting muscle coated cisterns in the subcutaneous tissues. It is also known as lymphangioma cavernosum (7). The second group included superficial lesions involving smaller areas with no subcutaneous abnormalities. The third group contained spongy lesions, found exclusively in areas where skin and mucosa are interwoven with striated muscle, such as tongue, lips and eyelids. In this last group there are fewer vesicles and numerous irregular superficial dermal lymphatic spaces (5).

The lesions may be scattered or grouped. The vesicles are translucent and contain fluid that may vary in color from clear

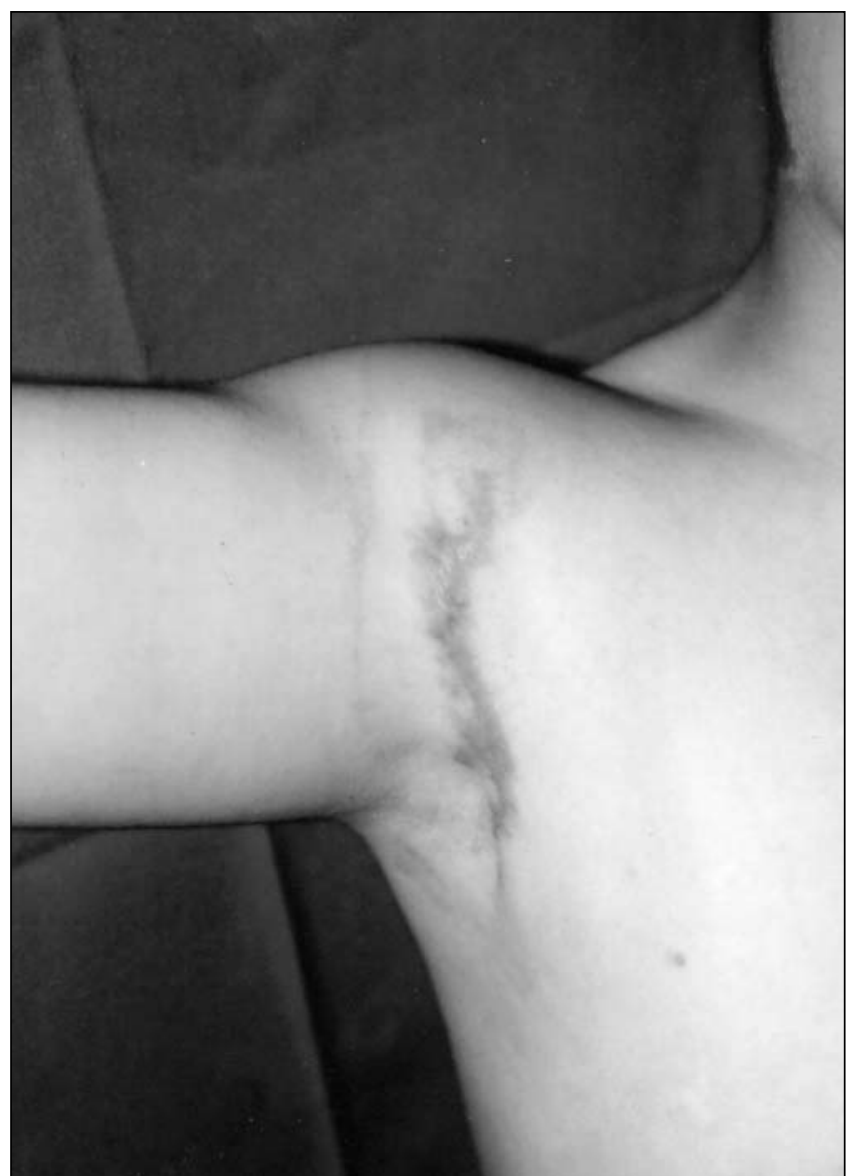

Figure 3) Six months later, there was a cosmetically and functionally acceptable postoperative result; no recurrence seen

to yellow to hemorrhagic. Tiny, blood-filled capillary tufts appear on the vesicle walls. At times, a warty hyperkeratosis may be superimposed over vesicles (6). In our case, vesicles were included in superficial lesions, and there were no subcutaneous abnormalities. The vesicles were grouped, and contained translucent fluid.

Complications of lymphangioma circumscriptum include leakage of fluid, recurrent lymphangitis and cosmetic deformity. There has been no malignant transformation reported to date (8).

Surgical treatment of superficial lymphangioma circumscriptum and the smaller classical lesions is $91 \%$ to $100 \%$ curative $(7,9)$. The surgical procedure is excision of the skin and underlying subcutaneous tissue. The larger classical lesions tend to recur following surgery, since the extent of subcutaneous involvement makes definition difficult and complete excision impossible. Cautery, cryotherapy, radiotherapy and carbon dioxide laser vaporization are helpful for surgical treatment of deep involvement, to improve cosmesis and to prevent complications. However, recurrences are still seen in classical lesions $(10,11)$. In our case, the lesion was excised and repaired with Z-plasty. No recurrence was seen. Six months later, the result was cosmetically acceptable. Careful excision of superficial lymphangioma circumscriptum prevented recurrence although there were difficulties defining the extent of subcutaneous involvement. 


\section{CONCLUSIONS}

In conclusion, we present a case of giant lymphangioma circumscriptum, $50 \times 120 \mathrm{~mm}$ in size, on the anterior axilla. We believed that it was successfully treated with excision plus Z-plasty, and that careful excision of superficial lymphangioma circumscriptum prevented recurrence although there was a difficulty in definition of the extent of subcutaneous involvement.

\section{REFERENCES}

1. LaPolla J, Foucar E, Leshin B, Whitaker D, Anderson B. Vulvar lymphangioma circumscriptum: A rare complication of therapy for squamous cell carcinoma of the cervix. Gynecol Oncol 1985;22:363-6.

2. Esquivias Gomez JI, Miranda-Romero A, Cuadrado Valles C, et al. Lymphangioma circumscriptum of the vulva. Cutis 2001;67:229-32.

3. Prioleau PG, Santa Cruz DJ. Lymphangioma circumscriptum following radical mastectomy and radiation therapy. Cancer 1978;42:1989-91.
4. Johnson TL, Kennedy AW, Segal GH. Lymphangioma circumscriptum of the vulva: A report of two cases. J Reprod Med 1991;36:808-12.

5. Goble RR, Frangoulis MA. Lymphangioma circumscriptum of the eyelids and conjunctiva. Br J Ophthalmol 1990;74:574-5.

6. Peachey RDG, Lim C-C, Whimster IW. Lymphangioma of the skin. Br J Dermatol 1970;83:519-27.

7. Flanagan BP, Helwig EB. Cutaneous lymphangioma. Arch Dermatol 1977;113:24-30.

8. Palmer LC, Strauch WG, Welton WA. Lymphangioma circumscriptum. A case with deep lymphatic involvement. Arch Dermatol 1978;114:394-6.

9. Browse NL, Whimster IW, Stewart G, Helm CW, Wood IJ. Surgical management of 'lymphangioma circumscriptum'. Br J Surg 1986;73:585-8

10. Van Cauwelaert P, Gruwez JA. Experience with lymphangioma. Lymphology 1978;11:43-8.

11. Eliezri ZD, Sklar JA. Lymphangioma circumscriptum: Review and evaluation of carbon dioxide laser vapourisation. J Dermatol Surg Oncol 1988;14:357-64. 